\title{
VARIACIONES DIARIAS EN CONCENTRACIONES PLAS- MÁTICAS DE SODIO Y POTASIO EN BOVINOS HOLSTEIN
}

\author{
Scaglione, M. C. ${ }^{1 ;}$ Cerutti, R. D. ${ }^{1} ;$ Althaus, R. L. ${ }^{1} ;$ \\ VAltorta, S. E.; DIAZ, D. C. ${ }^{1}$ \& BOgGIO, J. C. ${ }^{1}$
}

\begin{abstract}
RESUMEN
En rumiantes varios metabolitos y minerales podrían presentar variaciones diarias y estacionales. Algunos de ellos, como el $\mathrm{Na}^{+}$y el K+, juegan un papel importante en procesos biológicos, incluso en el equilibrio del agua. El objetivo del presente trabajo es determinar si las concentraciones plasmáticas de $\mathrm{Na}^{+}$y K${ }^{+}$presentan variaciones diarias y/o las estacionales en vacas en producción bajo un sistema de pastoreo. Para determinar variaciones diarias en las concentraciones plasmáticas de $\mathrm{Na}^{+} \mathrm{y} \mathrm{K}^{+}$dieciséis vacas en producción Holando argentino se asignaron al azar a cuatro tratamientos, cuatro animales cada uno, en Junio de 2.000. Los animales estaban en una granja comercial en Villa Trinidad, Santa Fe, Argentina, bajo un sistema de pastoreo base alfalfa, con dos ordeños diarios. En el tratamiento I, las muestras de sangre se tomaron vía la vena yugular a las 08:00 hs, con jeringas heparinizadas, luego se centrifugó y el plasma se almacenó a $5^{\circ} \mathrm{C}$ hasta el momento que se determinaron las concentraciones de $\mathrm{Na}^{+}$y $\mathrm{K}^{+}$. Los tratamientos II, III, y IV se realizaron de la misma manera, pero las muestras se tomaron a las 14:00; 20:00 y 02:00 horas, respectivamente. En noviembre de 2000, se llevó a cabo un nuevo ensayo con 16 animales. Los tiempos de muestreo para los ensayos I al IV fueron: 06:00; 12:00; 18:00 y 00:00 horas respectivamente, para mantener horas similares después del la salida del sol (HALO), i.e. 2, 8, 14 y 20 HALO. El análisis del cosinor fue realizado para determinar si las variaciones podían ajustarse a ritmos diarios. Las concentraciones plasmáticas de $\mathrm{Na}^{+}$estuvieron significativamente afectadas por la estación $\left(140,1 \mathrm{mmolL}^{-1}\right.$ en junio y $133,1 \mathrm{mmolL}^{-1}$ en noviembre; $\left.\mathrm{p}<0,05\right)$ ) y por el momento del muestreo. Las variaciones en junio y en noviembre no presentaron variaciones diarias. Las concentraciones plasmáticas de K estuvieron afectadas por el momento del muestreo en ambas estaciones. Sin embargo, ningún efecto estacional

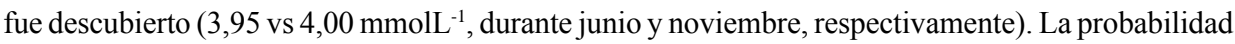
de variaciones en noviembre de $\mathrm{K}^{+}$para responder a un ritmo diario fue de 0,8 con Acrofase de $163^{\circ}$ radians a las 10:52 hs. En junio, las concentraciones plasmáticas de $\mathrm{K}$ no ser ajustaron a ritmos diarios. Se concluyó que a excepción de la variación plasmática del potasio durante el verano, las demás oscilaciones de los minerales no se ajustaron a ritmos diarios, sin embargo se piensa que podrían responder a mecanismos endógenos de medición del tiempo, ligada fundamentalmente a un ciclo de actividad-reposo, más que a un ritmo de luz-oscuridad.
\end{abstract}

Palabras clave: cronofisiología, $\mathrm{Na}^{+} ; \mathrm{K}^{+}$; vacas lecheras.

1.- Facultad de Ciencias Veterinarias, UNL. Kreder 2805. 3080, Esperanza, provincia de Santa Fe

2.- Investigadora. Consejo Nacional de Investigaciones Científicas y Técnicas (Conicet).

Manuscrito recibido el 21 de agosto de 2002 y aceptado para su publicación el 2 de abril de 2003. 


\section{SUMMARY}

\section{Diurnal variations in plasmatic concentration of sodium and potassium in holstein cows.}

Sixteen lactating Holando Argentino cows were randomly assigned to treatments, four animals each, in June 2000, to determine circadian variations in plasma $\mathrm{Na}^{+}$and $\mathrm{K}^{+}$concentrations. Animals were in a commercial farm in Villa Trinidad, Santa $\mathrm{Fe}$, Argentina, and were on an alfalfa based grazing system, with two daily milkings. In treatment I, blood samples were taken via the jugular vein at 08:00, in heparinized syringes, were then centrifuged and the plasma was frozen till analyzed to determine $\mathrm{Na}^{+}$and $\mathrm{K}^{+}$concentrations. Treatments II to IV were performed in the same way, but samples were taken at 14:00; 20:00 an 02:00 hours, respectively. In November 2000, the trial was carried out on 16 animals, the times for treatments I and IV being: 06:00; 12:00; 18:00 and 00:00 hours. Plasma $\mathrm{Na}^{+}$concentrations were significantly affected by season $\left(140.1 \mathrm{mmolL}^{-1}\right.$ in June and $133.1 \mathrm{mmolL}^{-1}$ in November; $\mathrm{p}<0.05$ ) and by sampling time. The cosinor analysis was performed in order to determine whether the variations could be adjusted to circadian rhythm. June and November variations did could not be fitted by cosinor. Plasma $\mathrm{K}^{+}$concentrations were affected by sampling time in both seasons. However, no seasonal effect was detected ( $3.95 \mathrm{vs} .4 .00 \mathrm{mmolL}^{-1}$, for June and November, respectively). The probability of November $\mathrm{K}^{+}$variations to respond to a circadian rhythm was 0.8 , the acrophase being $163^{\circ}$ radians, $10: 52$ hours. In June, $\mathrm{K}$ data could not be adjusted to a circadian rhythm, while an ultradian rhythm could be present. It was concluded that in this experimental conditions there was no clear circadian rhythm in $\mathrm{Na}^{+}$and $\mathrm{K}^{+}$plasma concentrations but the biological rhythms in this minerals throughout the day suggest to be due to the animal's biological clock response to changes not only to current ambient conditions, also to more integrative measures such as day length and a cycle of activity-rest .

Key words: chronophysiology; $\mathrm{Na}^{+} ; \mathrm{K}^{+}$dairy cows. 